\title{
Šiření renálního karcinomu dolní dutou žilou do pravostranných srdečních oddílů
}

\section{Ludmila Jarolímová}

II. interní klinika, Fakultní nemocnice a Lékařská fakulta Univerzity Karlovy, Plzeň, Česká republika

Adresa: MUDr. Ludmila Jarolímová, II. interní klinika FN a LF UK, E. Beneše 13, 30599 Plzeň, e-mail: jarolimoval@fnplzen.cz

Renální karcinom tvoří 90-95 \% primárních maligních nádorů ledvin ${ }^{1}$ a vyznačuje se sklonem $\mathrm{k}$ šíření žilním lumen. Nádorové tromby v renální a dolní duté žíle se uvádějí přibližně ve $4-10 \%$ prrípadů. ${ }^{2} \mathrm{Na}$ následující obrazové kasuistice chceme ukázat echokardiograficky dokumentované šírení takového trombu až do pravostranných srdečních oddílů.

Dvaaosmdesátiletá pacientka byla přijata na naše pracoviště pro sonograficky prokázanou hlubokou žilní trombózu levé dolní končetiny velkého rozsahu pokračující až do dolní duté žíly, zároveň bylo vysloveno podezření na tumor pravé ledviny s trombem v pravé renální žíle. Provedené CT vyšetření břicha potvrdilo prítomnost objemného tumoru dolního pólu pravé ledviny s rozsáhlou trombózou pravé ledvinné žíly a dolní duté žíly, s trombó-

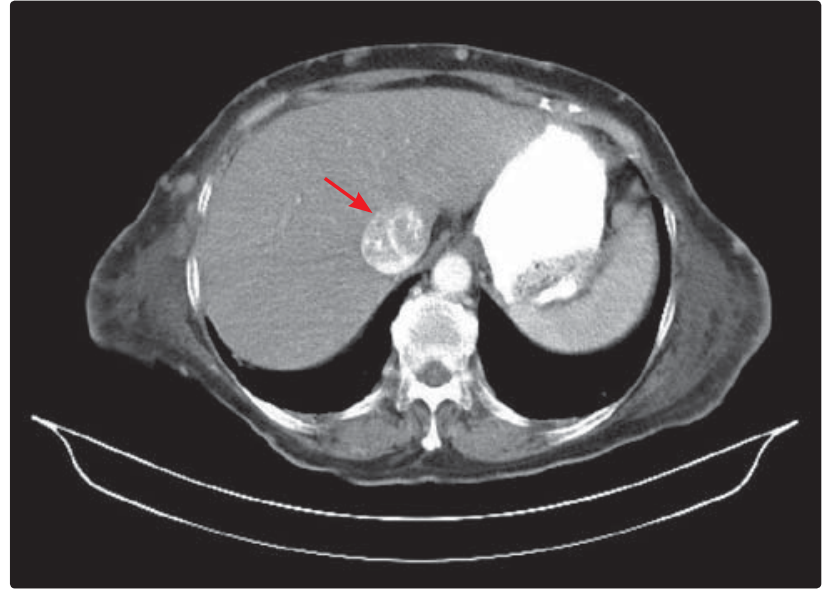

Obrázek 1 CT obraz nádorového trombu v dolní duté žile 


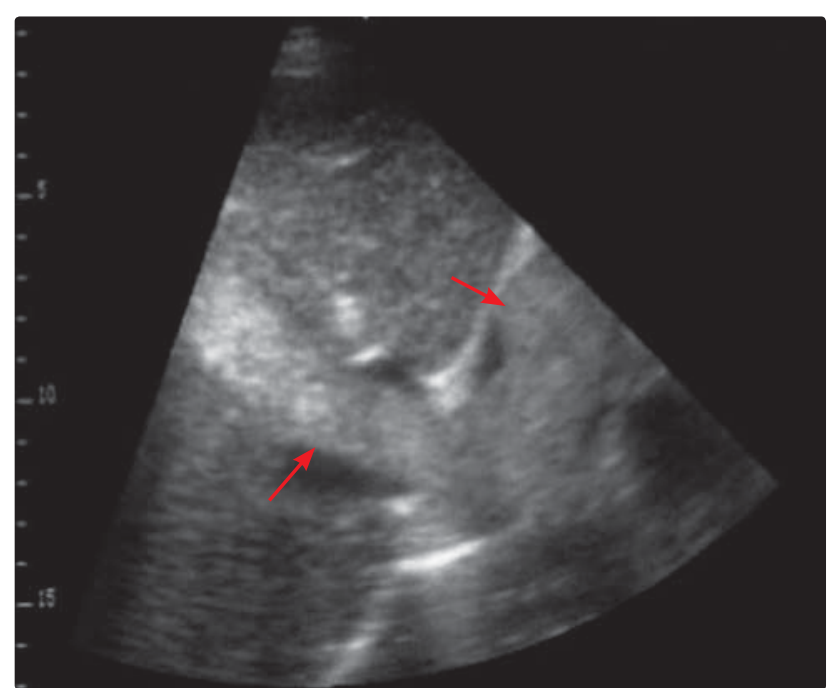

Obrázek 2 Kontinuální průběh tumorózního trombu dolní dutou žilou do pravostranných srdečních oddílů v echokardiografické subxifoideální projekci

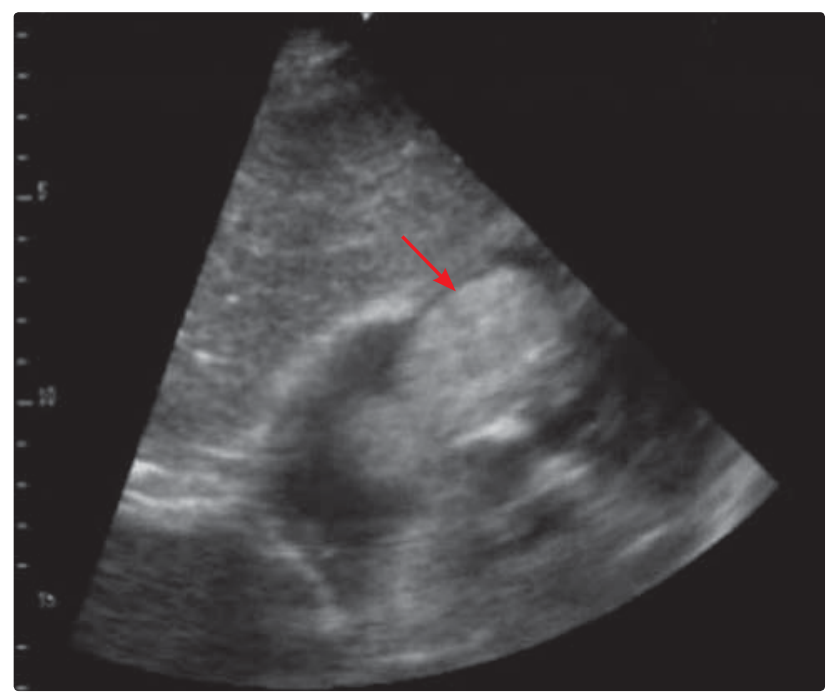

Obrázek 3 Distální konec tumorózního trombu prolabující trikuspidální chlopní do pravé komory v echokardiografické subxifoideální projekci

zou levostranného pánevního a femorálního řečiště, s pakety uzlin retroperitoneálně. Ještě bylo doplněno vyšetření PET-CT trupu s průkazem generalizace retroperitoneálně a suspekcí na plicní metastázy. V součinnosti s onkology a urology bylo vzhledem $\mathrm{k}$ rozsahu nálezu rozhodnuto o konzervativním postupu. Za hospitalizace byla nastavena účinná warfarinizace a posléze byla nemocná propuštěna v relativně uspokojivém stavu do domácí péče.

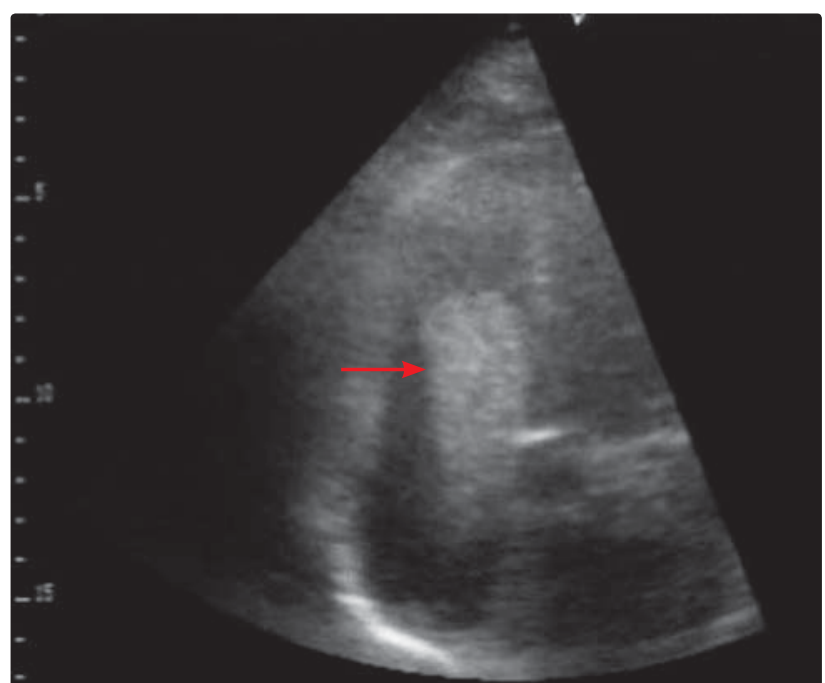

Obrázek 4 Distální konec tumorózního trombu prolabující trikuspidální chlopní do pravé komory v echokardiografické apikální čtyřdutinové projekci

S odstupem asi devíti měsíců byla nemocná rehospitalizována pro opakované pády. Krátce po přijetí došlo při chůzi na WC $\mathrm{k}$ dalšímu pádu a ke vzniku pertrochanterické zlomeniny pravého krčku femuru. $\mathrm{V}$ rámci vyšetření před operačním řešením dislokované fraktury bylo provedeno opakované CT vyšetření, při němž již tumor postihoval dvě třetiny pravé ledviny a trombus v dolní duté žíle (obrázek 1) byl patrný až k bránici. Bylo doplněno echokardiografické vyšetření srdce a při něm zjištěn útvar, nepochybně nádorový trombus, pokračující z dolní duté žíly do pravé srdeční síně (obrázek 2) a prolabující přes trikuspidální chlopeň do pravé komory (obrázky 3 a 4). I přes tento nález byla provedena operace zlomeniny a k doléčení byla nemocná přeložena na geriatrické oddělení. Tam s odstupem tří týdnů zemřela pod obrazem ledvinného selhání. Pitvána nebyla.

\section{Literatura}

1. Porter RS, Kaplan JL, eds. The Merck Manual Online. Whitehouse Station: Merck Sharp \& Dohme Corp. http://www.merck.com/mmpe/index.html.

2. Crawford ED, Woodside JR, Skinner DG, et al. Vena cava tumor thrombus from renal cell carcinoma arising from adrenal vein. Urology 1984;23: 538-540.

Došlo do redakce 29. 6. 2010

Prijato 11. 8. 2011 